\title{
FEEDBACK EXPRESSIONS USED BY AN ENGLISH TEACHER OF TOUR AND TRAVEL DEPARTMENT
}

\author{
Ratnah \\ Makassar Tourism Academy Science, Indonesia \\ email: ratna_akpar@yahoo.com
}

\begin{abstract}
Feedback as a part of teacher talk plays a crucial role in language learning. Feedback not only gives reinforcement to maintain good behaviors of the students but also makes students aware of the mistake they make during the learning and teaching process so that they are able to revise it. This study aims to identify the types of feedback expressions used by the teacher in teaching learning process, both positive and corrective feedback. The focus of the study was on the oral teacher feedback. To gather the data, one English teacher and her students who were studying English as a foreign language were observed while they were in a teaching learning process. Their interactions in the classroom were recorded, transcribed, and then analyzed to find out the types of feedback expressions used by the teacher during the interaction. The finding revealed that the teacher used both positive and negative feedback in the teaching and learning process. In terms of positive feedback, the teacher mostly used repetition, followed by praise and affirmation. In terms of negative feedback, the teacher also used a variety of ways which include repetition as the most common feedback provision, followed by recast, clarification request, elicitation, explicit correction, and prompting.
\end{abstract}

Key words: feedback expressions, positive feedback, negative feedback

\section{TUTURAN UMPAN BALIK SEORANG GURU BAHASA INGGRIS JURUSAN WISATA DAN PERJALANAN}

\begin{abstract}
Abstrak: Umpan balik sebagai bagian dari tuturan guru memiliki peran penting dalam pembelajaran bahasa. Umpan balik tidak hanya memberikan penguatan untuk mempertahankan perilaku baik para siswa, tapi juga menjadikan para siswa tersebut sadar atas kesalahan yang mereka buat selama proses belajar mengajar sehingga mereka dapat memperbaiki kesalahan tersebut. Kajian ini bertujuan untuk mengidentifikasi jenis-jenis ungkapan umpan balik, baik umpan balik positif maupun negatif, yang digunakan para guru dalam proses belajar mengajar. Fokus kajian ini adalah umpan balik lisan guru. Untuk mengumpulkan data kajian, seorang guru bahasa inggris dan para siswanya yang sedang belajar bahasa inggris sebagai bahasa asing diobservasi dalam proses belajar mengajar. Interaksi mereka di kelas direkam, dibuat catatan rekaman, dan kemudian dianalisis untuk mengetahui jenis-jenis ungkapan umpan balik selama interaksi. Hasil kajian menunjukkan bahwa guru menggunakan umpan balik positif dan negatif dalam proses belajar mengajar. Dalam hal umpan balik positif, guru tersebut seringkali menggunakan pengulangan, yang diikuti oleh pujian dan penguatan. Dalam hal umpan balik negatif, guru juga menggunakan ungkapan umpan balik yang beragam, meliputi pengulangan sebagai umpan balik yang sering digunakan, diikuti oleh perombakan, permintaan klarifikasi, elisitasi, koreksi ekplisit, dan memberikan petunjuk.
\end{abstract}

Katakunci: ungkapan-ungkapan umpan balik, umpan balik positif, umpan balik negatif 
Teacher talk has been widely studied in relation to studies of language learning. Studies of teacher talk can take the forms of the investigation of language that teachers use in their language classrooms and the investigation of language that they use in subject matter lessons. One of the teacher talks that is frequently used in the classroom activity is the language the teachers use in giving feedback to students. Feedback is any information or expressions which provide a report on the result of a certain behavior (Richards, Platt, \& Platt, 1992). Feedback is useful to examine the success or the failure of performance. By providing feedback to students, they will be aware that their performance is acceptable or not. In language learning, feedback focuses almost all aspects of language elements and language skills. It can take the forms of verbal, non-verbal feedback expressions, positive feedback, negative feedback, and neutral feedback. Moreover, feedback covers both oral and written production.

In studies on oral production, there is some evidence revealing that feedback can help learners to be successful in the process of teaching and learning. Ligtbown and Spada (1993), for example, found that feedback within a communicative context contributes to the higher level of linguistic knowledge and performance. Feedback on oral production, as one of the teacher talks can be both positive and negative. Positive feedback can generally be defined as expressions used when students provide correct response on the teacher's questions in order to reinforce the students' behavior. Vigil and Oller (1976) propose that positive feedback may take the form of praise markers such as "OK," "fine," "good," and "excellent" as well as a positive personal response. I would call this "non-corrective feedback". Negative feedback, on the other hand, can be defined as expressions used when the teacher intends to correct the students' erroneous utterances or responses. Such negative feedback can be in the forms of explicit and implicit feedback. (Lyster and Ranta, 1997) termed this as "corrective feedback." They divide corrective feedback into 6 types: explicit correction, recasts, asking for clarification, meta-linguistic feedback, elicitation, and repetition.

Providing feedback to learners' production is very important for the teacher in teaching learning interactions. Feedback not only gives reinforcement to maintain good behaviors of the students (as we can find in the positive or non-corrective feedback) but also makes students aware of the mistake they make during the learning and teaching process (as we can find in negative or corrective feedback). Considering the significance of the use of feedback, this paper will then identify the types of feedback the teacher used in the teaching and learning process in the classroom. The types of feedback were identified through a process of classroom observation and an analysis of lesson transcripts. The data were taken from a classroom interaction, where the teacher was teaching English to the tenth grade students on the topic "Narrative." The data were taken on September $27^{\text {th }}, 2011$. The paper will focus on the positive or non-corrective feedback and negative or corrective feedback the teacher used during the class sessions.

Teacher talk is defined in different ways. Richards, Platt, and Plat (1992) define teacher talk as the variety of language used by teachers in the process of teaching and learning. According to them, teacher talk includes the simplification of teacher speech and styles of speech addressed to language learners. Parrish in Weddel (2008) states that teacher talk is the language that teachers use in class. Parrish divides teacher language or teacher talk into six categories: warm-up chats, direct instruction, giving, directions, giving feedback, making transitions, and checking understanding. Moreover, Cullen (1998) divided teacher talk into two main cate- 
gories: Communicative and non communicative teacher talks. He lists some features of communicative teacher talks as follows:

1. The use of 'referential' questions, where the teacher asks the students something that he or she really does not know the answer, and which therefore has a genuine communicative purpose.

2. Content feedback by the teacher, where the teacher focuses his/her feedback on the content of what the students say which is related to the message not on form.

3. The use of speech modifications, hesitations, and rephrasing in the teacher's own talk, e.g. when explaining, asking questions, giving instructions, etc.

4. Attempts to negotiate meaning with the students, for example the teacher asks for clarification and repetition, and giving opportunities for the students to interrupt the teacher and do the same (p.181)

While the communicative teacher talks have certain features, the non-communicative teacher talks also have specific features. According to Cullen (1998) the features of non-communicative teacher talks include:

1. Exclusive or excessive use of display questions.

2. Form-focused feedback, that is, the feedback given by the teacher which focuses on the correct formation of the students' utterances or answer, not on the content.

3. 'Echoing' of students' responses, when the teacher repeats what a student has just said for the benefit of the whole class.

4. Sequences of predictable IRF (initiation-response-feedback) discourse chains in which the teacher initiates the chain (typically by asking a question), a student responds, and the teacher then gives feedback to the student (e.g. 'good') before initiating another chain with another question (p. 182).
Based on the definitions, the types and the features of teacher talk presented above, it is concluded that feedback is one element of the teacher talks, both in communicative and non-communicative teacher talks. Feedback can focus on form and content. Feedback from the teacher to the students' responses is either an acknowledgement that the answer is acceptable (positive feedback) or an indication that it needs correcting (corrective feedback).

\section{Concepts of Feedback}

Feedback as one part of teacher talk is defined by Sliger in Reigel (2005) as "language-related responses to learners' utterances, upon which the learner is focused and which can be used by the learner to validate or invalidate concepts he or she has about the target language." Moreover, Richards, Platt, and Platt (1992) define feedback as comments or information a learner receives from the teacher on the success of a learning task. This definition emphasizes on the use of positive feedback as what Fossati (2008) said that positive feedback is the response provided to some correct input from the students and this type of feedback can help them reinforce the correct knowledge they already have, or successfully integrate new knowledge. Negative feedback, on the other hand, can be provided by the teacher in response to students' mistakes and this type of feedback can help the student correct a mistake and prevent them from making the same or similar mistake again. Lyster \& Ranta (1997) and Lightbown \& Spada (1993) called this negative feedback "corrective feedback". Lightbown \& Spada (1993) state that corrective feedback is an expression used to indicate to a learner that his or her use of the target language is not correct. The types of positive and corrective feedback are discussed in the following sessions. 


\section{Positive feedback}

Positive feedback in learning can be provided in different ways. Vigil and Oller (1976) for example, propose that positive feedback may take the form of praise markers such as "OK," "fine," "good," and "excellent" and/or all preceding terms + "job" or "work" such as "excellent work" or "nice job". Furthermore, Vigil and Oller state that Positive feedback not only has a metalinguistic component (praise) but also a linguistic component (affirmation) and a paralinguistic component (laughter). Reigel (2005) also summarized that positive feedback contains:

1) A paralinguistic component which includes such responses as uh huh or head nodding to convey agreement or that the message has been received and is understood. It also includes laughter and other nonverbal cues

2) A linguistic component, including the "personal response" —a mechanism of interpersonal communication that includes a speaker and hearer; manifested by affirmation.

3) A metalinguistic component, taking the form of evaluative feedback, including praise markers such as "fine," "good," "excellent." (p. 32)

Kohn (1993) also provides the forms of "positive feedback." He said that feedback can be straightforward information about how well someone has done at a task. Kohn (1993) terms this type of positive feedback "informational feedback." There are also "verbal rewards" that feel controlling and make one dependent on someone else's approval" .In addition, Cullen (1998) proposed that repeating students' correct response can be categorized as positive feedback. He said that the teacher's repetition of a student's response acts as a signal confirming that the response is correct.

Based on the explanation of positive feedback, it is concluded that positive feedback in the process of teaching and learning can take the instances of: a. Praise, such as the use of expressions "good," "great," "excellent," "nice," etc.

b. Affirmation, such as the use of expressions "yes, "correct," "OK," "that's right," etc.

c. Non-verbal cues, such as laughter, nodding, and thumbs up.

d. Repetition, namely repeating the correct response of the student.

\section{Negative or corrective feedback}

Negative or corrective feedback has drawn the attention of a lot of researchers. Chaudron (1988), for example, identifies corrective feedback as "any teacher behavior that minimally attempts to inform the learner of the fact of error." He proposed three moves after the student's initial error. The first one is follow-up move, in which the teacher reacts to the error either accepting, evaluating, or commenting on the error. The second is Opening move in which the teacher conveys information relating to the error by some implicit or explicit ways, and the third is answering move, in which the student will then reply again. Similarly, Lightbown and Spada (1993) define corrective feedback as "any indication to learners that their use of target language is incorrect" and this feedback can be either explicit or implicit, and may include metalinguistic explanation or not. Furthermore, the types of corrective feedback were studied comprehensively by Lyster and Ranta (1997). They identified 6 types of feedback including:

1. Explicit correction in which teacher provides the correct form and clearly shows that what the student had said was incorrect;

2. Recasts is the teacher's reformulation of all or part of the student's utterance in a correct form

3. Elicitation is when the teacher directly elicits a reformulation from students by asking questions such as How do we say that in English?" or by having a pause to let students complete teacher's 
utterance, or by asking students to reformulate their utterance;

4. Metalinguistic clues is the feedback in the forms of comments, information, or questions related to the well-formed utterance of the students;

5. Clarification requests is when teacher uses phrases such as "Pardon?" and "I don't understand" to ask for a clarification from the students;

6. Repetition is when the teacher repeats the student's ill-formed utterance, adjusting intonation to highlight the error. (p. 46)

From the 6 types of corrective feedback studied by Lyster and Ranta above, it was found that teachers mostly used explicit correction on students' error. In another study Lyster (1998) investigated the role of corrective feedback in learner uptake. In this study, he divided the corrective feedback only into three types: recasts, explicit correction, and negotiation of form. The difference with the previous classification (Lyster \& Ranta, 1997) is that in this classification, Lyster includes repetition, elicitation, and clarification request as one category, namely nego- tiation of form. In this research, he found that the negotiation of form were more effective at leading to immediate repair than recasts or explicit correction.

Another form of corrective feedback is "prompting." This prompting is also recommended in order to shape the correct response from the students. Yanfen and Yunqin, (2010) stated that "when students produce no answer or an incorrect answer, teachers usually prefer ways of prompting to get students to work out the answer by themselves, and this is what teachers really did in class." They furthermore said that a prompt is an attempt to get the participants produce the correct answers by the use of a clue to indicate the location and the nature of the errors. In this case, prompting can also be done by requesting the student to make a clarification of what he has just said. The examples of such feedback expressions are: "A verb isn't suitable here, what do you think you can use here?" "Are you sure this is the way they do?" "Can you think of another way to say it?"

Finally, the types of positive and corrective feedback can be summarized as follows:

\begin{tabular}{|c|c|c|c|}
\hline $\begin{array}{l}\text { Positive } \\
\text { Feedback }\end{array}$ & Examples of expression & $\begin{array}{l}\text { Corrective } \\
\text { feedback }\end{array}$ & Examples of expression \\
\hline Praise & Fine, excellent, good & $\begin{array}{l}\text { Explicit } \\
\text { correction }\end{array}$ & $\begin{array}{l}\text { S: She go to school } \\
\text { T: Not she go to school. You } \\
\text { should say "She goes to school" }\end{array}$ \\
\hline Affirmation & $\begin{array}{l}\text { "OK", "yes", "that's right," } \\
\text { "I understand it" }\end{array}$ & Recasting & $\begin{array}{l}\text { S: I eat a lot yesterday } \\
\text { T: Oh, you ate a lot yesterday. }\end{array}$ \\
\hline $\begin{array}{l}\text { Non-verbal } \\
\text { cues }\end{array}$ & Nodding, smile, thumb up & $\begin{array}{l}\text { Clarification } \\
\text { request }\end{array}$ & $\begin{array}{l}S: \text { we went to the birth party } \\
T: \text { do you mean birthday party? }\end{array}$ \\
\hline \multirow[t]{4}{*}{$\begin{array}{l}\text { Repetition } \\
\text { (echoing) }\end{array}$} & $\begin{array}{l}S: \text { the color of the house } \\
\text { changed } \\
T: \text { The color of the house } \\
\text { changed }\end{array}$ & $\begin{array}{l}\text { Repetition (with } \\
\text { rising } \\
\text { intonation) }\end{array}$ & $\begin{array}{l}\text { S: We went to the birth party } \\
\text { T: You went to the birth party? }\end{array}$ \\
\hline & & Elicitation & $\begin{array}{l}\text { How do say that in English?, Do } \\
\text { you mean X? }\end{array}$ \\
\hline & & $\begin{array}{l}\text { Metalinguistic } \\
\text { explanation }\end{array}$ & $\begin{array}{l}\text { S: She go to school every day } \\
T: \text { the sentence is present tense, } \\
\text { so the verb should be "goes" }\end{array}$ \\
\hline & & Prompting & $\begin{array}{l}\text { The first letter is " } O \text { " and the } \\
\text { last letter is " } N \text { " }\end{array}$ \\
\hline
\end{tabular}




\section{METHOD}

This research is qualitative research which attempts to analyze the use of teacher talks in the classroom, which is limited to the use of verbal feedback, both positive and negative feedback. The subjects of this research were one of the English teacher and the first semester students of Tour and Travel Department of a Tourism Academy in Makassar who were involved in English teaching and learning process. The data were collected through classroom observation in a natural interaction between the teacher and the students. The activity that lasted one hour and fifteen minutes was recorded using a special means designed especially for recording.

The data were analyzed in the following procedure: (1) Transcribing the recorded data, (2) Classifying the data based on the types of feedback found in the research, (3) Reducing the data, taking only the data which showed significant contribution to the variables being studied, (4) Giving codes to each piece of extracts that is going to be discussed in the research, (5) Analyzing the data in terms of the types of feedback investigated, and (6) Interpreting the data in order to answer the research questions.

\section{FINDINGS AND DISCUSSION}

From the transcribed data, it was found that the teacher used both verbal positive and negative (corrective) feedback. In relation to positive feedback, the teacher used 3 different types of feedback: (1) praise, (2) affirmation, and (3) repetition or echoing. In terms of corrective feedback, the teacher used 6 types of feedback: (1) repetition, (2) recast, (3) clarification request, (4) elicittation, (5) explicit correction and (6) prompting. How the teacher provided different feedback expressions can be seen in the following analysis.

\section{Positive Feedback}

Repetition

Extract 1
In this extract the teacher (T) was asking the students about the definition of narrative. The conversation took place between the teacher and students.

Teacher: Did you learn narrative?

Remember about narrative? What is it about? What is it about? Narrative? Do you remember anything about narrative? You wanna say something? ((looking at one of the students). Give me a word about narrative. Come on. Say something about narrative. Yes, you wanna say something? Narrative?

Student : Narrative is a story of a....

Teacher: It's a story. Let me give you a word....... What else you know about narrative?

Student : Story about animals

Teacher: Story about animals, yes, what else? What else you know about narrative? Ok, Nobody knows about narrative? Nobody else wanna add? More words about narrative? You need that computer? ((asking one student who was working with a laptop)) ok, thank you. Ok, Now hmm... If we talk about narrative, remember what you learnt when you were in junior high school?

\section{Extract 2:}

In the following extract the teacher was telling a narrative story to students by showing related pictures through the LCD projector. The conversation talked about the change of color in the pictures based on the flow of the story.

Teacher: That's why they could see him.

She could see him when he slept on the

bed. But Wilbur was not allowed to sleep on the bed......So, Winnie put him outside. Outside in the grass. When Wilbur sat outside in the grass, Winnie couldn't see him, do you know why?

Student :Because they have the same color Teacher: yes, because they have the same color, the grass was green and Wilbur was green too, even when his eyes 
were wide open. Her eyes, his eyes color are, uhmm, what's his eyes color?

Student : green

Teacher: green, so Winnie came hurrying outside, tripped over Wilbur, turned three somersaults, and fell into a rosebush. You can see that, look at, look at Winnie, poor Winnie, upside down, ok, we can see her leg. This time, Winnie was furious. She picked up her magic wand, waved it five times, not only one five times, say 1, 2 and after top and... what does it say?

In the two above extracts, the teacher repeats the students answer to reinforce the students who answered the question correctly. When the teacher asked the question: What else you know about narrative, The students answers: "story about animals" and the teacher repeats the students' answer by saying "story about animals,..". Another repetition can be shown in extract 2 where the teacher repeated the student's utterances: yes, because they have the same color and green. The use of a lot of repetitions characterized the way teacher gave positive feedback. Cullen (1998) called this kind of repetition "echoing." He said that 'echoing' of students' responses means that the teacher repeats what a student has just said for the benefit of the whole class. Cullen's study also found that echoing is mostly characterized teacher talk in the classroom.

\section{Giving praises}

Giving praises to the students' correct responses such as "fine", "good job", and "excellent" is also featuring this classroom interaction. The form of praises used by the teacher can be seen in the following extracts:

\section{Extract 3}

In this extract the teacher ( $\mathrm{T}$ ) approached the students and was asking some of them whether they have finished their job or not.
Teacher: Done? No need to do with something that...... Focus on the dialogue, focus on the dialogue, that's not that important. Focus on the dialogue and you think about. They're almost done, think about the dialogue. ((the teacher was examining the students' work)) ok, that's good,, really good. Have your paper? Don't litter, Don't litter! Excellent, very good, can I, can I, borrow for awhile?

((The teacher was showing the students' paper to other students)). Can you see this one? Isn't it good? Ok, that's good, ok. Keep working. Keep on working. Excellent! Sorry, you can start cutting the first two.((speaking to one of the students)) And you cut and you put it here, ok, you can start work, while he is writing, you start cutting the first two and put it here.

Student : ok.

Teacher: And you continue working on that ok? Alright! I'll show you the example. Can I borrow this? Just keep on working on this, see the example, ok? Good! Keep on working, you decide, you make up on while waiting her cutting, just like dialogue. Very good!((praising students who did the task correctly)).

Yummy, yuummyy yummy

You have already two? You already have two, You cut the first two and let him do the cutting. Let me show you the example let me show you the example, ok, so you know how to do it. Very good, excellent

Student: ini tentang percintaan bu [This is about love, Ma'am]

Teacher: Ok! Dialogue, work on your dialogue first. Whatever the names, you can give any names you wish... ..Ok, yah that's fine. (looking and praising another student who did the task correctly)). You write again, just like that. Ok how is it going? How is it going? Good, very good! 
The extract above contains a lot of praises, indicating that the teacher used a lot of positive feedback. The use of different expressions such as "good," "very good," "excellent," and "fine" dominates other teacher talks used in this classroom. These kinds of praise were used when the teacher gave appreciation to students who did the task correctly. This is in line with what Cullen (1998) said that feedback from the teacher to the students' responses is either an acknowledgement that the answer is acceptable (e.g. by echoing) or by a comment such as 'fine'. As can be seen in the extract above, the expressions of praise used by the teacher mostly addressed the task that the students were working on. She praised the students who did the task correctly and these praises are considered as positive feedback to maintain students' good behavior. According to Thomas and Blote in Reigel (2005), praise is positive reinforcement that can give positive effect and is a more intense response to student behavior and this positive feedback mechanism is able to amplify and induce repeated behavior.

\section{Affirmation}

The next positive feedback found in the interaction is affirmation, which shows whether the students' response or message has been understood. Reigel (2005) added that affirmation is the expressions used to affirm that something said is true, indicated by such markers as "right," "correct," "true," "OK," and/or "yes" (not the one uttered in response to a yes/no or direct question). The following two extracts show how the teacher affirmed the students' responses.

\section{Extract 4}

In this extract the teacher (T) was discussing the elements of a narrative. The teacher tried to make the students recall the three elements of a narrative.
Teacher: There are 3 things that we need to keep in mind about narrative. There are 3 things when telling narrative, main important things. The first is....

Student: past tense

Teacher: yeah we use past tense, yes.

Thank you, that's good. We use past tense in narrative, yes. One of it, and any other things that you remember about narrative? About story, yes. What story? One of you says it's about animal, yes

\section{Extract 5}

In this extract the teacher (T) tried to remind the students about how they should order the picture that she gave to them.

Teacher : You know the order?. Discussed the order already?. Yeah. ok. You need to discuss with your friend, to decide to decide the order the arrangement. Why you didn't bring one? ((asking a student who did not bring scissors with him)) Ok, ok come on move on. Let them discuss. Hey come on, start to... , start from number?

Student : six

Teacher: Ok, number six. Good! Ok, come on... ((examining the students work)). OK! Done, good, good, hhmm ((looking at one of the students' paper)). OK, OK, OK. Now it doesn't mean that you have the same order.

\section{Extract 6}

Student: I think have fun is not about live in colorful house. When you have friends it means you have fun with them, so Winnie shouldn't kick Wilbur out

Teacher:Ok. Ok. So Having fun doesn't mean living......?

Ss: living in colorful house

In the three extracts above, it was found that the teacher used a lot of expressions of "Yeah," "yes" and "OK." However, not all of those expressions can 
be categorized as affirmation. In extract 6 , the teacher used "yeah" to affirm the student's response "past tense" because this response was the correct response expected by the teacher. Even the affirmation was followed by the use of "yes, thank you, that's good" to ensure that the response was correct. In extract 7, the teacher used "OK" to affirm that the answer of the student "six" is correct, then it was followed by repetition of the correct response and a praise. However, the consistent use of " $O K$ " by the teacher does not necessarily mean that the teacher affirmed the correct response of the students. It can be an indication to move to another activity.

\section{Negative or Corrective Feedback}

From the transcribed data, it was found that the teacher used 6 different types of feedback expressions, namely: repetition, recast, clarification request, elicitation, and explicit correction. Metalinguistic explanation was not likely to be used by the teacher. The following show the extracts in which the teacher used such corrective feedback.

\section{Repetition}

According to Lyster and Ranta (1998), one of the corrective feedback expressions that can be used by the teacher is repeating student's erroneous utterance with adjustting intonation to highlight the error. This kind of corrective feedback can be found in the following extract.

In this extract the teacher (T) was checking understanding of the students about the story, especially their understanding about the resolution part of the story.

\section{Extract 7}

T: Wilbur just went to climb the top of the tree. And that's what happens. Wilbur was sad and Winnie was sad too. Winnie didn't like him to be upset actually too be miserable but then she realized, then what's resolution? How's the problems solved?

$S$ : Winnie changed the color of the house

$T$ : Winnie changed the color of the house? Do you agree with that? So that, Instead of changing Wilbur color, But Winnie changed the color of the house, then what happened to Wilbur? Winnie changed the color of Wilbur. Back to....?

S: black...

T: back to its origin color, ok, so .... so Wilbur become black and then back to color of black and the house become colorful. Ok, hmm, that's the....

The above extract shows how the teacher repeated the student's utterance with rising intonation to give an indication that the answer was not correct. The teacher repeats: "Winnie changed the color of the house? with rising intonation as if it is a question. This repetition is followed by a real question: "do you agree with that?" implying that there might be something wrong with the student's answer, and finally the teacher gives the correct answer by saying: "Winnie changed the color of Wilbur."

Recasts

Another type of feedback the teacher used in the teaching learning activity is recasts. Recasting is the reformulation of student's utterance in a correct form minus the error. The example of a recast can be found the following extract.

\section{Extract 8}

In this extract, the teacher and the students discussed the moral value implied in the story that teacher had told them.

Student : I think have fun is not about live in colorful house. When you have friends it means you have fun with them, so Winnie shouldn't kick Wilbur out 
Ratnah, Feedback expressions used by an english teacher of...

Teacher: Ok. Ok so. Having fun doesn't mean living?

Students: living in colorful house

Teacher: living in colorful house. The real meaning, colorful, the real color, colorful house and..

Student :But when you friends it means you have fun

Teacher:We have friends then we have fun so,

Student :Real friends

The above extract shows the use of recasts, that is when the teacher reformulates the student's response by providing the correct form or answer. In the extract above, the student (S) says: $I$ think have fun is not about live in colorful house. This response was perceived by the teacher as having incorrect form, especially the use of the word "have" that should take the ing-form. Therefore, she reformulated this utterance in the correct form by saying: "Having fun doesn't mean living.....? and all of the students (Ss) continued her sentence: "in a colorful house." In this case, the teacher implicitly corrects the student's utterance by focusing on the form of the utterance.

Another recast the teacher used in the above extract is when the student said: "But when you friends it means you have fun". The meaning of this sentence may not be clear for the other students to understand and the teacher might think that this utterance contained a problem in meaning; therefore, the teacher reformulated the utterance by saying: "We have friends then we have fun so."

\section{Clarification Request}

The next corrective feedback used by the teacher is clarification request. When the teacher found something wrong in the students' utterance, then she asked for clarification by using phrases such as "Pardon?" and "I don't understand" and so on (Lyster \& Ranta, 1997). The following extract shows this kind of feedback.

\section{Extract 9}

In this extract the teacher (T) and the students discussed the moral value of the story.

Teacher : Ok we don't change everything as we wish

Student: Because it can make mistakes

Teacher: Aha...that's it, What do you mean by making mistakes here?

Student: She want it maybe we don't have same reason

Teacher: She wants it. Maybe you don't. So she has different reasons and you have your own reasons.

The extract above shows that the teacher asked for clarification about the meaning of "mistake" by asking her "what do you mean by making mistake here?" She focused her correction on meaning. Then the student gave explanation about what she meant by "mistake" in her utterance. However, because the teacher felt that the student's utterance still contained errors related to the structure and the meaning of the sentence, then the teacher gave another form of feedback to repair the student's sentence, namely in the form of recasting by saying: "She wants it. Maybe you don't. So she has different reasons and you have your own reasons."

Another example of clarification request can be seen in the following extract. In this extract the teacher was still trying to elicit response from the students concerning the meaning of narrative. One student expressed his answer in Bahasa Indonesia.

\section{Extract 10}

Student : pengalaman ((whispering))

Teacher : sorry? About....? About what?

Student : experience

Teacher : about experience, yes , whose experience?

Student :uhmm someone 
In the above extract, the teacher asked for clarification for the student's answer expressed in Bahasa Indonesia which may be perceived by the teacher as an unacceptable response. In this case, the teacher wanted her student to say it in English. That's why she asked the student to clarify the answer and the teacher confirmed that the answer is true by repeating it and said "yes". Different from extract 9, in which the teacher provided the student with the correct answer, in this extract, the student gave the correct answer by himself.

\section{Elicitation}

According to Lyster \& Ranta, (1997), elicitation is the feedback made by the teacher by directly eliciting a reformulation from students by asking questions such as "How do we say that in English?" or by pausing to allow students to complete teacher's utterance, or by asking students to reformulate their utterance. What is found in the transcribing data was that the teacher used elicitation by pausing her utterance to allow students to complete her utterance and also by asking students to reformulate their own utterance. The example of these types of feedback can be seen in the following extracts:

\section{Extract 11}

In this extract the teacher ( $\mathrm{T}$ ) asked one of the students to repeat what his classmate had just said about the message of the story. She tried so hard to make the student speak.

\section{S1: it just same we don't having fun}

$T$ : ok, that's good, good, Excellent. So, you know what she.... Did you hear what he said just now? ((asking another student)). Did you hear what he said just now?

S2: no

$T: O k, n o$ ! because you couldn't hear his voice or because you talk with your own? Ok, now let's listen again. Make sure you hear what he said. Ok, Say it again, say it again!

S1: if we live in just one or two

colors means we don't live in

fun

$T$ : ok, ok anybody wanna say it again, say it again. Do you wanna say it again? ((asking another student $)$ )

S3 : ((silent $))$

$T$ : if we.... , What did he say? If we... .? If we......?

S3: $m m m \ldots . .$.

$T$ : If we live in two colors or three colors it means that....., what he said, it means that......? we don't live.....? we don't have .....? We don't live in.....?

S3: fun

T: Yeah, fun, so we don't have fun, that's what he said.

This extract shows how hard the teacher encouraged the student to elicit correct utterance. The teacher repeated the sentence: "if we..... , "it means that....." several times and paused in the middle of the utterance to allow students to complete her utterance. However, because the student could not continue her sentence, (the students still found it difficult to elicit a single word), the teacher then supplied some more words and gave another pause to allow him to continue the sentence but he still failed. At the end, when the teacher said: "We don't live in...." the student was successful to complete the teacher's utterance by saying "fun" and the teacher accepted this answer by affirming and repeating the student's answer. This type of feedback can be categorized as elicitation.

\section{Explicit Correction}

In the teaching and learning activity, the teacher also used explicit correction in which she provided the student with the correct form and clearly showed that the student's utterance was not acceptable or incorrect. The example of this type of 
feedback can be seen in the following extract.

\section{Extract 12}

In this extract the teacher $(\mathrm{T})$ tried to elicit answer from the students concerning the three elements of narrative.

S1: object

T: sorry? No! Not object

S2: observation

\section{T: No}

S2: oh I forgot

S3: orientation

$T$ : orientation! Perfect! Orientation, ((writing the word "Orientation" on the board)). Remember that? you know that. Ok, see, you know that

The above extract shows the use of explicit correction in which the teacher explicitly said that the answer of the student was wrong. Rather than providing the correct answer for the students, the teacher just waited for the students to give correct answer. This is different from what Lyster (1998) said that in explicit correction, the teacher provides the correct form of the language. However, this is still acceptable as an explicit correction because the teacher explicitly showed and stated that the student's utterance was wrong. Unfortunately, in the teaching and learning process under this study, the teacher used this type of feedback once.

\section{Prompting}

The last type of corrective feedback used by the teacher is prompting. It is the clue given by the teacher when students do not give an answer or incorrectly answer the question. The following extract shows how the teacher provided prompts to encourage the students to give correct response.

\section{Extract 13}

In this extract the teacher $(\mathrm{T})$ tried to elicit answer from the students (S) concerning the elements of a narrative story.

$T$ : someone's experience, your experience can be,... you can..., you can make it in narrative, yes. What else? ((Students were silent). When we write a narrative, what 3 main important things that we need to pay attention? It's not just like you write without any organization, the first thing you need is to pay attention to the 3 main things in narrative. Remember that?

Ss : ((silent $))$

$T$ : the first is talking about? Don't you remember? In narrative? I give you the clue, $O$, start with $O$

$S$ : object

$T$ : sorry? Not not object

$S$ : observation

$T: N o$

$S$ : oh Iforgot

$S:$ Orientation

\section{$T$ : Orientation! Perfect!}

Orientation, remember that.

The extract above showed that when the students did not know the answer of the question, teacher provided a prompt to students to get students to work out the answer by themselves, and this is what the teacher actually did in this interaction. The students strived hard until they could answer the question correctly and the teacher followed her feedback by repeating the students' answer "orientation" and by praising them using the expression "perfect."

After presenting the data analysis, the following table summarizes the findings of the research.

\begin{tabular}{|c|c|c|}
\hline \multirow{2}{*}{ Examples of Teacher Expressions } & \multicolumn{2}{|c|}{ Types of Feedback } \\
\hline & Positive Feedback & Negative Feedback \\
\hline $\begin{array}{l}S: \text { Story about animals } \\
T: \text { story about animals, yes, what } \\
\text { else? What else you know about }\end{array}$ & $\begin{array}{l}\text { Repetition, that is, when the } \\
\text { teacher repeated the student's } \\
\text { answer to indicate that his }\end{array}$ & \\
\hline
\end{tabular}


narrative? (Extract 1)

$T$ : .....ok, that's good, really good. Have your paper? Don't litter, Don't litter! Excellent, very good, can I, can I, borrow for awhile? (Extract 3)

answer is right.

Giving Praises, in which the teacher praised the student' work by using such expressions as "good," "nice," "great," "excellent," etc.

$T$ : yeah we use past tense, yes. Thank you, that's good. We use past tense in narrative, yes. (Extract 4)
S: past tense

Affirmation: in which the teacher used expressions "yes, "correct," "OK," "that's right," to affirm that the student's answer was right.

$S:$ the color of the house changed

T: The color of the house changed? Do you agree with that? (Extract 7)

T: I think have fun is not about live in colorful house. When you have friends it means you have fun with them, so Winnie shouldn't kick Wilbur out

$T:$ Ok. Ok so. Having fun doesn't mean living....?

Ss: living in colorful house (Extract 8)

$T:$ Ok we don't change everything as we wish

$S$ : Because it can make mistakes $T$ : Aha...that's it, What do you mean by making mistakes here? $S$ : She want it maybe we don't have same reason. (Extract 9)

$T:$ if we...., What did he say? If we....? If we......?

S3: $m m m$.....

$T$ : If we live in two colors or three colors it means that....., what he said, it means that......? we don't live.....? we don't have .....? We don't live in.....?

S3: fun

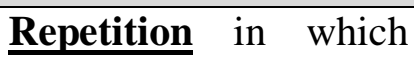
the teacher repeated the student's answer with rising intonation as if it is a question to indicate that there is something wrong with the student's answer

$\underline{\text { Recasts, }}$ in which the teacher reformulated all or part of the student's utterance in a correct form.

Clarification requests, in which the teacher used question "What do you mean by ....." to ask for a clarification from the students

Elicitation, in which the teacher provided the part of the sentence with a pause to let students complete teacher's utterance, or by asking students to reformulate their utterance; 


\begin{tabular}{|c|c|}
\hline $\begin{array}{l}\text { T: Yeah, fun, so we don't have fun, } \\
\text { that's what he said. (Extract 11) }\end{array}$ & \\
\hline $\begin{array}{l}\text { S1: object } \\
T: \text { sorry? No! Not object } \\
\text { S2: observation } \\
T: \text { No } \\
\text { S2: oh I forgot } \\
\text { (Extract } 12 \text { ) }\end{array}$ & $\begin{array}{l}\text { Explicit correction: } \\
\text { the teacher provides the } \\
\text { correct form and } \\
\text { clearly shows that what } \\
\text { the student had said } \\
\text { was incorrect by saying } \\
\text { "No, Not object". }\end{array}$ \\
\hline $\begin{array}{l}T: \ldots \ldots . \text { In narrative? I give you } \\
\text { the clue, } \boldsymbol{O}, \text { start with } \boldsymbol{O} \\
S: \text { object } \\
T: \text { sorry? No..... Not object } \\
S: \text { observation (Extract } 13 \text { ) }\end{array}$ & $\begin{array}{l}\text { Prompting, that is, } \\
\text { when student produced } \\
\text { no answer or an } \\
\text { incorrect answer, the } \\
\text { teacher gave a clue to } \\
\text { get students to work } \\
\text { out the answer by } \\
\text { themselves, }\end{array}$ \\
\hline
\end{tabular}

In extract 8 the teacher focused her feedback on the grammatical structure of the student's utterance. This type of feedback can be categorized as noncommunicative feedback which is one of the elements of non-communicative teacher talk. This is also supported by Cullen (2005) who included "form-focused feedback" as one of the noncommunicative teacher talk. Cullen said that form-focus feedback is the feedback which is given by the teacher focusing on the correct formation of the students' utterances or answer, not on the content. In this case, as can be seen in extract 8 , the teacher used recast to correct the student's errors in using the forms "have" and "want." She repeated the student's utterance with the correct formation of sentence.

From a number of feedback types which are potentially used by the teacher, she did not use metalinguistic clues or explanation to correct the students' error. Metalinguistic clues are the feedback expressions in the forms of comments, information, or questions related to the well-formed utterance of the students (Lyster \& Ranta, 1997). Metalinguistic comment that can be found in the teacher feedback was the use of praise expressions to acknowledge that the student's utterance is correct. This can be found in extract 3 , in which the teacher used such expressions as "good," and "excellent" to praise the student's correct answer. Reigel (2005) called this metalinguistic component, that is, the form of evaluative feedback, which includes praise markers such as "fine," "good," "excellent."

The analysis also shows that repetition, as one of the feedback types, can be found both in positive and negative feedback. The difference is that the repetition that is used in positive feedback indicates that the student's answer is correct, so the teacher repeated the student's utterance, with normal intonation to ensure that the answer is acceptable as can be seen in extract 1 . On the contrary, the repetition used in corrective feedback indicates that the student's answer is incorrect and the teacher repeated the student's answer with rising intonation to make the student aware that there is something wrong with the answer.

\section{CONCLUSION}

Based on the findings of this research, it is concluded that in the teaching and learning interaction, the teacher used different types of feedback expressions as parts of teacher 
talk. The feedback expressions take the forms of positive feedback which aim to acknowledge that the students' answer is correct. The types of positive feedback used by the teacher include praises, affirmation and repetition, while the types of corrective feedback used by the teacher include repetition, recasts, elicitation, explicit correction, and clarification request. Metalinguistic explanation was not used by the teacher because the activity did not focus on linguistic forms but it focused on the content of the lesson in a very communicative activity.

Based on the findings of the study, it is suggested that the teachers of English apply more types of feedback in order to provide students with opportunities to repair or improve their language. This study took the data from only one meeting of the lesson. Hence, it will be better for further researchers to extend their observation to more than one meeting so that they can explore more types of feedback used in the classroom interaction.

\section{REFERENCES}

Chaudron, C. (1988). Second language classrooms: Research on teaching and learning. Cambridge, UK: Cambridge University Press.

Cullen, R. (1998). Teacher talk and the classroom context. ELT Journal, 52(3) pp. $179-187$.

Fossati, D. (2008). The role of positive feedback in intelligent tutoring systems. Proceedings of the ACL-08: HLT Student Research Workshop (Companion Volume), pp. 31-36,

Kohn, A. (1993). Punished by rewards: The trouble with gold stars, incentive plans, A's, praise, and other bribes. New York: Houghton-Mifflin.

Lightbown, M. P. \& Spada, N. (1993). How Languages are learned. Oxford: Oxford University Press.

Lyster, R. (1998). Negotiation of form, recasts, and explicit correction in relation to error types and learner repair in immersion classrooms. Language Learning 48(2), pp. 183218

Lyster, R., \& Ranta, L. (1997). Corrective feedback and learner uptake: Negotiation of form in communicative classroom. Studies in Second Language Acquisition, 19, pp.37-66.

Reigel, D. (2005). Positive feedback loop in second language learning. Unpublished MA TESOL Thesis, Portland State University.

Richards, J.C., Platt, J., \& Platt, H.(1992). Longman dictionary of language teaching and applied linguistics. England: Longman.

Vigil, N., \& Oller, J. (1976). Rule fossilization: A tentative model. Language Learning, 26(2), 281-295.

Weddel, K.S. (2008). ESL teacher language (teacher talk) for effective classroom interactions: Independent study course for teachers of adult English as a second language (available at www.cde.state.co.us/ClassroomTeache rLanguageSelfStudyMod0508.pdf. Accessed on October 11, 2011). Yanfen, L \& Yunqin, Z. (2010). A study of teacher talk in interactions in English classes. Chinese Journal of Applied Linguistics (Bimonthly),33(2), pp.76-86. 